\title{
Guillaume-Benjamin Duchenne: a miserable life dedicated to science
}

\author{
Guillaume-Benjamin Duchenne: uma vida de sofrimento dedicada à ciência \\ Péricles MARANHÃO-FILHO',2, Maurice VINCENT ${ }^{3}$
}

\begin{abstract}
Duchenne de Boulogne is known mainly by the disease eponymously named "Duchenne muscular dystrophy", or pseudohypertrophic muscular dystrophy, although some experts consider that the original description of this disease does not belong to him. Less well known are the facts related to the tragic death of his beloved wife shortly after the birth of his only child, the unjustifiable distance he was forced to keep from this son for more than 30 years, and of being humiliated and professionally despised by his peers. These events made the life of this physician, physiologist, researcher and inventor extremely arduous. We emphasize some aspects of the history of this man, his work and his life, a true genius of few friends.
\end{abstract}

Keywords: Duchenne de Boulogne; electrophysiology; muscular dystrophy.

\section{RESUMO}

Duchenne de Boulogne é conhecido por muitos principalmente devido à doença que leva seu nome - doença de Duchenne ou Distrofia Muscular Pseudo-hipertrófica - embora alguns historiadores considerem que a descrição original desta doença não lhe pertence. Menos conhecidos são os fatos relacionados à morte trágica de sua amada esposa logo após o nascimento de seu filho, o afastamento injusto que foi forçado a manter deste filho único por mais de 30 anos, e ser humilhado e profissionalmente desprezado por seus pares da comunidade neurológica, que em conjunto tornaram a vida desse médico, fisiologista, pesquisador e inventor, extremamente árdua. Enfatizamos alguns aspectos da história deste homem, seu trabalho e ocaso, protótipo de um verdadeiro gênio de poucos amigos.

Palavras-chave: Duchenne de Boulogne; eletrofisiologia; distrofia muscular.

Duchenne muscular dystrophy (DMD) is a genetic, still incurable disease, caused by mutations in the gene encoding the dystrophin protein. More than 180 years after the recognition of this devastating disorder, technology may finally allow reparation of the defective human DMD gene ${ }^{1}$. We review some aspects of Duchenne's life, the neurologist who unveiled DMD.

\section{THE MAN}

The H. M. Lugger, Marechal de Cobourg, commissioned in Boulogne in May 1793, captured the French vessel Espoir on 12 December 1796, a ship first led by PierreLouis-Nicolas Hardouin plus 37 men crew, and after 1795 by Jean-Pierre-Antoine Duchenne. The Treaty of Amiens, signed in 25 March 1802 as the "Definitive Treaty of Peace", would not last beyond May 1803. Bonaparte resumed his plan to invade England and left Paris, heading towards the North Sea on 24 June, with the intention of setting up an important military and naval base, centered in Boulogne-sur-Mer². Guillaume-Benjamin-Amand Duchenne was born in this city (17 September 1806), during a war between the two countries that, ironically, mostly contributed to the development of Neurology during that period. Guillaume inherited his courage and determination from his father, Jean-Pierre-Antoine Duchenne, the commander of the Espoir, who was awarded the Légion d'Honneur by Bonaparte ${ }^{3}$.

Short, overweight, active in movement but slow in speech, the younger Duchenne, considered shy and hard-working, retained his faint provincial accent ${ }^{4}$. Age turned him bald with thick sideburns (Figure 1). As an ingenious observer, 1 Universidade Federal do Rio de Janeiro, Hospital Universitário Clementino Fraga Filho, Departamento de Clínica Médica, Serviço de Neurologia, Rio de
Janeiro, RJ, Brasil;

${ }^{2}$ Universidade Federal do Rio de Janeiro, Rio de Janeiro, RJ, Brasil;

${ }^{3}$ Eli Lilly and Company, Neuroscience Research, Indianapolis, USA.

Péricles Maranhão-Filho (iD) https://orcid.org/0000-0003-2030-547X

Correspondence: Péricles Maranhão-Filho; Av. Prefeito Dulcídio Cardoso 1680 / 1802; 22620-311 Rio de Janeiro RJ, Brasil; E-mail: pmaranhaofilho@gmail.com

Conflict of interest: Maurice Vincent is a stock-holding employee at Eli Lilly and Company.

Received 15 October 2018; Received in final form 23 November 2018; Accepted 21 January 2019. 
he became one of the most prestigious clinicians of the 19th century ${ }^{5}$. He adopted his "de Boulogne" suffix to distinguish himself from Edouard Adolphe Duchesne, an esteemed physician of the Paris aristocracy ${ }^{6}$.

\section{THE LIFE}

Duchenne entered medical school in Paris in 1827, graduating in 1831 (thesis: Essai sur la Brûlure, 34 p.). After his father's death, he returned to Boulogne and became a physician.

In December 1831, he married the young Mlle. Barbe Boutroy, who died of puerperal sepsis two weeks after giving birth to their son, Guillaume-Maxime Emile Duchenne, in January $1833^{5}$. His mother-in-law held him responsible for the death of her daughter, as Duchenne was involved in the delivery of the child. Confused and depressed by this tragedy, Duchenne mistakenly allowed his mother-in-law to take care of his son. She unfairly prevented Duchenne from having any contact with the boy, a separation that persisted for more than 30 years ${ }^{7}$. Desperate and hopeless, Duchenne abandoned his clinic. At home, he sought consolation in reading and

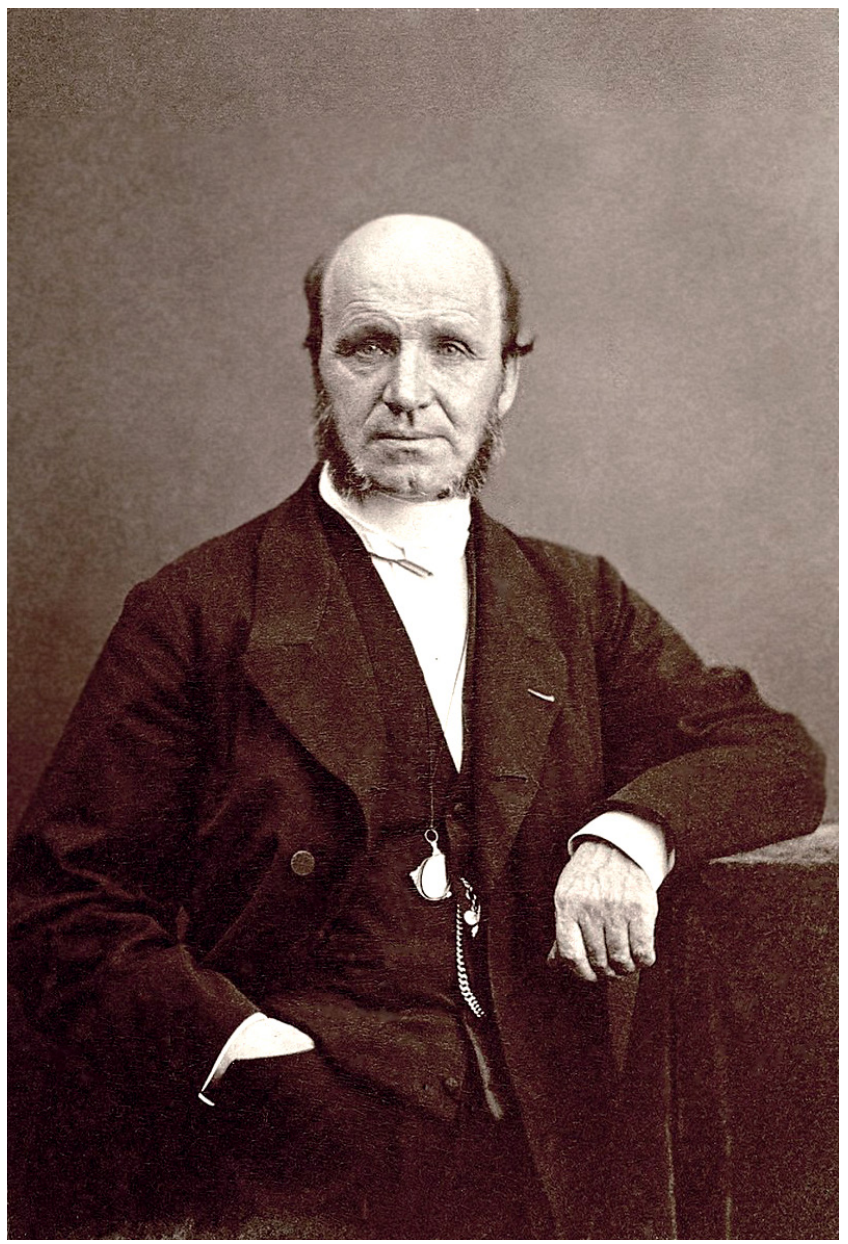

Photo from: https://en.wikipedia.org/wiki/Duchenne_de_Boulogne Figure 1. Guillaume-Benjamin-Amand Duchenne (de Boulogne). playing Bach and Beethoven on his violin ${ }^{3}$. He progressively returned to his patients, peers and their families. He eventually married a young widow, his distant cousin, Honorine Lardé, in 1839, whose extrovert personality contrasted with her quiet, recluse and absent-minded husband ${ }^{5}$.

Duchenne left Boulogne for Paris in 1842, with the intention of developing research on l'électrisation localisée (the effect of faradic current on the function of skeletal muscles). As a provincial physician, without any personal appeal, lonely, isolated from his friends and with little money, his beginning in Paris was difficult ${ }^{7}$. Established physicians rejected his ideas and opinions to the point of humiliation. He was never given a hospital or university appointment ${ }^{3}$. However, Duchenne continued to work hard, making detailed notes on all patients, often applying his electrical treatment methods. He examined patients every morning with laborious obsession, often following their progress by visiting them at home for many years. His reputation slowly improved ${ }^{8}$. Duchenne talked to his patients or watched them silently for hours with scrupulous attention, a technique sometimes called "the contemplative method”, adopted later by Charcot, Déjerine and Grasset.

He was reunited with his son in Paris in 1862. He started to gain international respect, and was eventually elected to many medical societies across Europe 4 .

\section{THE WORK}

In 1835, Duchenne questioned why an electric current produced a localized muscle contraction. His curiosity soon became an obsession. He realized he could stimulate muscles using two metallic electrodes (rhéophores) applied to the moist skin $^{4}$. He patiently built his own faradic current induction instrument for stimulation of muscles and nerves (Figure 2).

In 1849, Duchenne described a patient with spreading progressive muscular atrophy, starting in the hands and slowly affecting the arms and legs, with no sensory deficits, pain, or sphincter dysfunctions. He did not publish this case but passed on his observations to François Amilcar Aran, a physician at the Hôpital Saint Antoine ${ }^{4}$. The first edition of Duchenne's book De l'electrisation localisée et de son application à la thèrapeutique was published in 1855. In the second edition, Duchenne described pseudohypertrophic muscular dystrophy ${ }^{9}$, a disease that, according to Gowers ${ }^{10}$, isolated cases that had already been recognized by Charles Bell (1830) and Partridge (1847). The first detailed case series were published by the physicians Edward Meryon (1852) and Oppenheim $(1855)^{11}$.

Duchenne's contributions included works on the use of photography of microscopic histology, tabetic locomotor ataxia (mistaken for Friedreich's ataxia at the time), anterior horn cell lesions, which caused acute poliomyelitis, and glosso-labial-laryngeal paralysis (bulbar palsy). He was the 

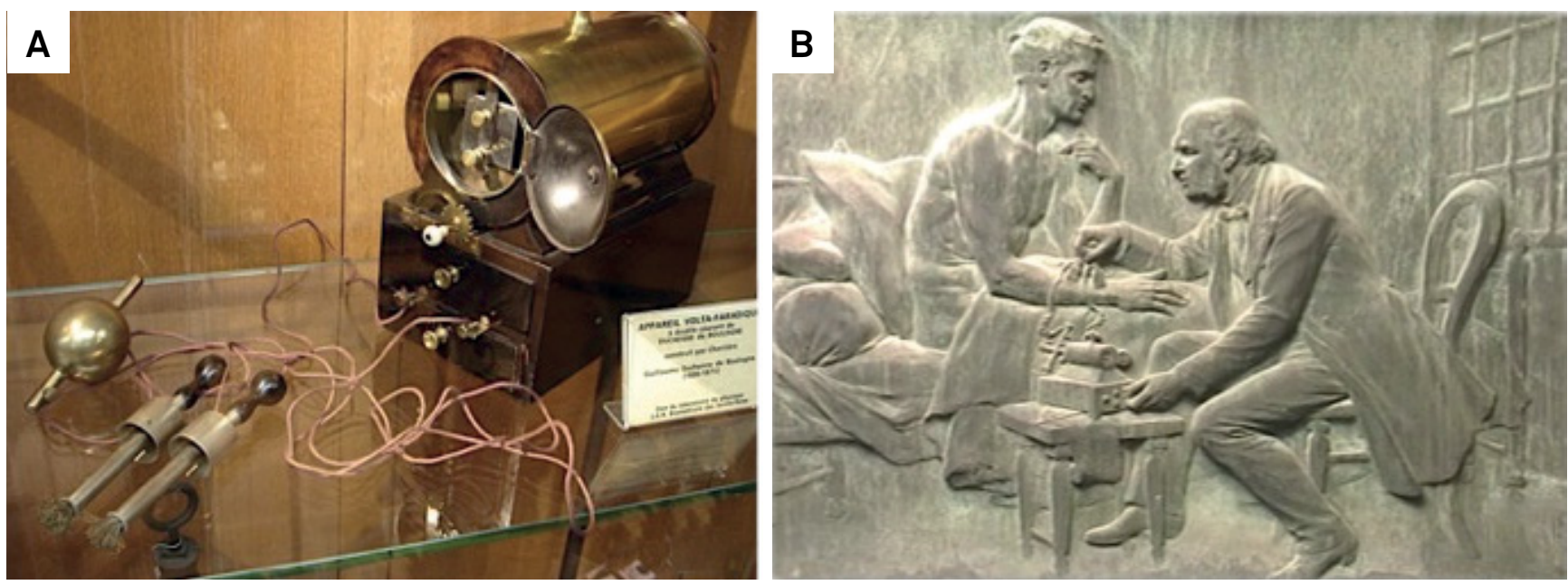

Figure 2. (A) The faradic voltage induction apparatus idealized by Duchenne. Musée d'histoire de la médecine, Paris. PM-F photograph. (B) A bas-relief medallion shows Duchenne using the apparatus and stimulating the forearm muscles of a patient lying in his bed ${ }^{12}$

first clinician to perform muscle biopsies with the invention he called l'emporte-pièce.

Duchenne published over 90 articles and books ${ }^{8,12}$. His monograph, the Mécanisme de la physionomie humaine ${ }^{13}$, prominently illustrated with photographs - the first study on the physiology of emotion - was highly influential in Darwin's work on human evolution and emotional expression ${ }^{14}$.

\section{THE SUNSET}

His daughter-in-law took care of Duchenne during his declining years. He visited England, Austria and Spain, but remained depressed despite all the recognition he received. Ambitious "colleagues" stole some of his papers, but Duchenne seemed indifferent to this ${ }^{12}$. His second wife, Honorine, died in December 1870. Less than a month later, typhoid fever took his beloved son Guillaume-Maxime. Unfortunately, four years later, Duchenne, with his personal life completely devastated, suffered a cerebral hemorrhage ${ }^{5}$. Charcot, who slept in his friend's room for several days, was his physician during the last days, until his death, two days before completing the age of $69^{7}$.

A medallion in his honor stands at the entry of the amphitheater at the Myology Institute, Babinski Building, Hôpital Pitié-Salpêtrière ${ }^{12}$ (Figure 2B).

\section{References}

1. Duchêne BL, Cherif K, lyombe-Engembe JP, Guyon A, Rousseau J, Ouellet DL, Barbeau X, Lague P, Tremblay JP. CRISPR-Induced deletion with SaCas9 restores dystrophin expression in dystrophic models In Vitro and In Vivo. Mol Ther. 2018 Nov;26(11);2604-16. https://doi.org/10.1016/j.ymthe.2018.08.010

2. Wimet, P-A. Boulogne et le rêve conquérant de Napoléon In: Lottin, A., diretor. Histoire de Boulogne-sur-Mer: ville d'art et d'histoire. Villeneuve d'Ascq: Presses Universitaires du Septentrion, 2014. p. 211-30.

3. Hudson P. Duchenne's dystrophy. In: Kehler P, Bruyn G, Pearce J, editors. Neurological eponyms.. New York: Oxford University Press; 2000. p. 301-8.

4. Pearce J. Some contributions of Duchenne de Boulogne (1806-75). J Neurol Neurosur Psychiatry. 1999 Sep;67(3):322. https://doi.org/10.1136/jnnp.67.3.322

5. Parent A. Duchenne De Boulogne: a pioneer in neurology and medical photography. Can J Neurol Sci. 2005;32(3):369-77. https://doi.org/10.1017/S0317167100004315

6. Plotogea AVA, Keresztes A, Moarcas M. Guillaume-Benjamin-Amand Duchenne - between medicine and art. Bull Transilvania University of Brașov. 2009;6(51):185-8.
7. Hustvedt A. Medical muses. Hysteria in Nineteenth-Century Paris. New York: W. W. Norton; 2011.

8. Poore GV. Clinical works of Dr. Duchenne (de Boulogne). The New Sydenham Society, London, 1883. In: Selections from the clinical works of Dr. Duchenne (De Boulogne). London: Forgotten Books; 2018.

9. Duchenne GBA. De L'Electrisation localisee et de son application a la pathologie et a la therapeutique. 2nd ed. Paris: Bailliere, 1861.

10. Emery AE. Duchenne muscular dystrophy: Meryon's disease. Neuromuscul Disord. 1993;3(4):263-6. https://doi.org/10.1016/0960-8966(93)90018-F

11. Gowers WR. A manual of diseases of the nervous system. Philadelphia: P. Blankiston; 1888.

12. Emery AEH, Emery MLH. The history of a genetic disease: Duchenne muscular dystrophy or Meryon's disease. 2nd ed. Oxford: Oxford University Press; 2011.

13. Duchenne GBA. Mécanisme de la physionomie humaine, ou analyse électro-physiologique de l'expression des passions. Paris, Chez VE Jules Renouard; 1862. Vol 1.

14. Mauro HP. Duchenne: discourses of aesthetics, sexuality, and power in nineteenth-century medical photography. Athanor. 2000;18:55-61. 